\title{
呼吸困難をさたした甲状腺襄胞例
}

\author{
冨田 俊樹1) 井上 貴博1) $・$ 川崎 篤 2$) \cdot$ 山崎 一人 ${ }^{3)}$
}

\section{A Case of Thyroid Cyst with Dyspnea}

\author{
Toshiki Tomita and Takahiro Inouye \\ (Tochigi Prefecture Saiseikai Utsunomiya Hospital) \\ Atsushi Kawasaki and Kazuto Yamazaki \\ (Keio University School of Medicine)
}

\begin{abstract}
A case of thyroid cyst that presented with a sudden onset of dyspnea is discussed. The patient was a 62-year-old female who had an anterior cervical tumor for several decades. She had had upper respiratory infection and had felt an enlargement of the tumor for a week before onset. A $60 \times 70 \mathrm{~mm}$ round, smooth, cystic mass was present on the right side of the anterior portion of her neck. X-ray films of the neck showed a remarkable stenosis and a deviation of the trachea to the left. CT scan of the neck revealed a large cystic mass in the right lobe of the thyroid gland. Dyspnea was improved after open biopsy of the mass in the right lobe of the thyroid. Histologic examination of the biopsy specimen showed thyroid cyst. Enucleation of the thyroid cyst was performed.

Dyspnea was precipitated by upper airway obstruction with rapid enlargement of the cyst and an increase of sputum due to upper respiratory infection.
\end{abstract}

Key words : thyroid cyst, dyspnea, upper airway obstruction

はじめに

甲状腺腫瘍が短期間に急速に増大し，気管の著明な狭 窄をきたし呼吸困難を生じた場合，まず未分化癌あるい は分化癌の未分化転化が疑われる.甲状腺良性腫瘍性病 変が上記の病態を呈することは非常に稀である.

今回われわれは呼吸困難を主訴に来院した甲状腺囊胞 の 1 例を経験したので, 若干の検討を加えて報告する.

\section{症例}

患者 : 69歳, 女性.

主訴：呼吸困難.

現病歷 : 約30年前より前頸部腫瘤を自覚するも放置し ていた。1994年 2 月初旬より感冒様症状があり, 同時に
前頸部腫瘤の腫大を自覚していたところ，同年 2 月 9 日 突然の呼吸困難をさたし，当院救急救命センターを受診 した。前頸部腫瘤による気道狭窄が疑われたため当科依 頼となった.

既往歴 : 10年前よりC型慢性肝炎.

家族歴 : 特記すべきことなし.

初診時所見：吸気性の呼吸困難および軽度のチアノー ゼを認めた。動脈血ガス分析では, room airにて, $\mathrm{PaO}_{2} 48.3 \mathrm{mmHg}, \mathrm{PaCO}_{2} 38.5 \mathrm{mmHg}, \mathrm{sO}_{2} 71.6 \%$ であ った. 喉頭ファイバースュピーでは異常所見を認めなか った。

局所所見としては, 前頸部に約 $60 \times 70 \mathrm{~mm}$ の表面平 滑, 弾性硬で可動性不良な腫瘤を触れた。圧痛や皮膚の

1）栃木県済生会宇都宮病院耳鼻咽喉科

2) 慶応.義塾大学医学部耳鼻咽喉科学教室

3）慶応義塾大学医学部病理学教室 
発赤を認めず，頸部りンパ節は触知しなかった。

血液検查所見：白血球 $24.9 \times 10^{3} / \mathrm{mm}^{3}$ 之高值の他は, 末梢血液, 生化学和よび甲状腺機能はすべて正常で, サ イロイドテスト怙よびマイクロゾームテストは㓌性であ った。

画像所見: 頸部単純レントゲン正面像(図 $1 \mathrm{a}$ )では, 気管は左方へ強く圧排され，側面像(図 1 b) では気管前 部の軟部組織陰影の腫大と気管の著明な狭窄が認められ た.

造影 CT (図 2 ) では, 前頸部に $45 \times 49 \mathrm{~mm}$ 大の囊胞 性腫瘤を認め，これにより気管は著明に圧排され前後方 向の狭窄をきたしていた。腫瘤は甲状腺右葉より連続し て扮りままた甲状腺を超党た進展は認めなかった。

画像所見より気管の著明な狭窄が確認されたため緊急 入院の上, 気道の確保々甲状腺腫瘍の組織学的検查を目 的飞, 同日, 気管切開術扮上び腫瘍生検術を局所麻酔下 に予定した.

術中所見: 胸骨 1 横指上に横切開を加光, 前頸筋群を 左右に分け腫痬前面を露出させた（図３）。画像にて左方

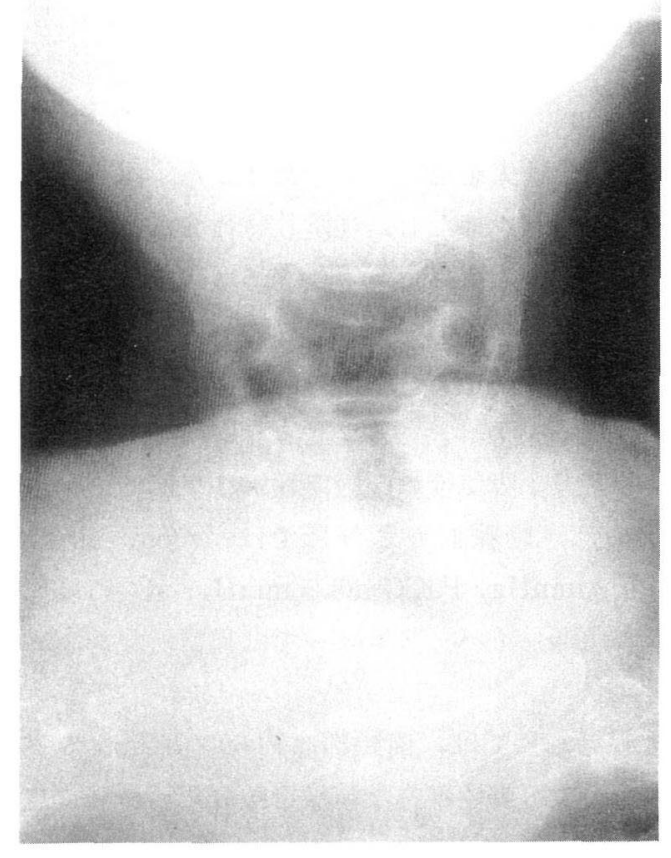

図 $1 \mathrm{a}$ 頸部単純レントゲン正面像 気管は左方へ強く压排されている.

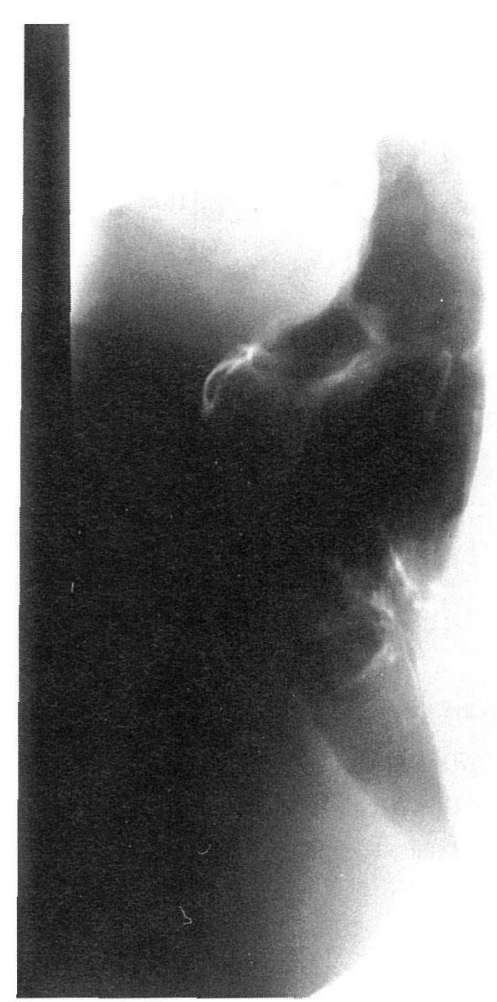

図 1b 頸部単純レントゲン側面像

気管前部の軟部組織の腫大と気管の著明な狭窄を認め る.

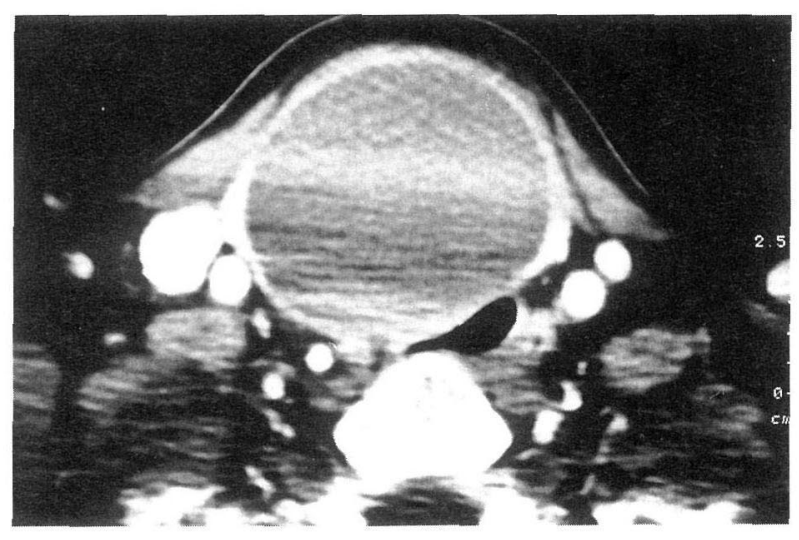

図 2 造影 CT

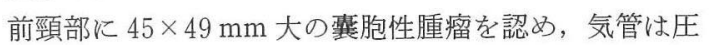
排され狭窄をさたしている。

に偏位した気管は同定不能であった。腫瘍は囊胞性で, 切開を加光たところ約 $30 \mathrm{cc}$ の褐色膿性内容液が流出し 


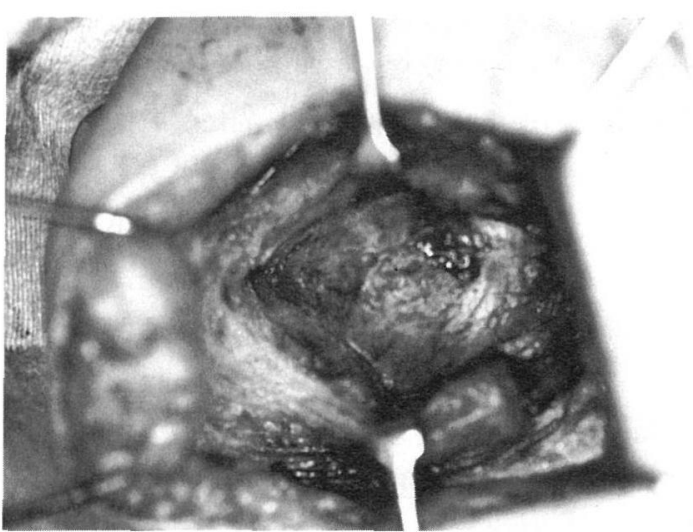

図 3 術中写真

前頸筋群を左右に分け腫瘍前面を露出させた。

た。同時に呼吸困難は自覚的に解消されたため気管切開 は施行しなかった。褧胞壁の一部を生検目的に切除し， 襄胞内にドレーンを留置し，手術を終克た。

生検の病理組織学機診断は，良性囊胞性変化をきたし た結節性過形成单あるいは濾胞腺腫であった。

術後経過：生検術後の動脈血ガス分析結果は room air そて, $\mathrm{PaO}_{2} 40.1 \mathrm{mmHg}, \mathrm{PaCO}_{2} 84.5 \mathrm{mmHg}, \mathrm{sO}_{2}$ 96.5\%と著明に改善していた。

2 月18日(術後 9 日目)の Gd-DTPA 造影 T1 強調 MRI （図 4 ）では，境界明瞭な輬胞性腫瘤は intermediate T1 lesion と long T1 lesionが界面形成を呈して抒り， enhancement は認めなかった。術前のCT に比べると， 気道の狭窄は改善されていた。また，99m Tc シンチグラ

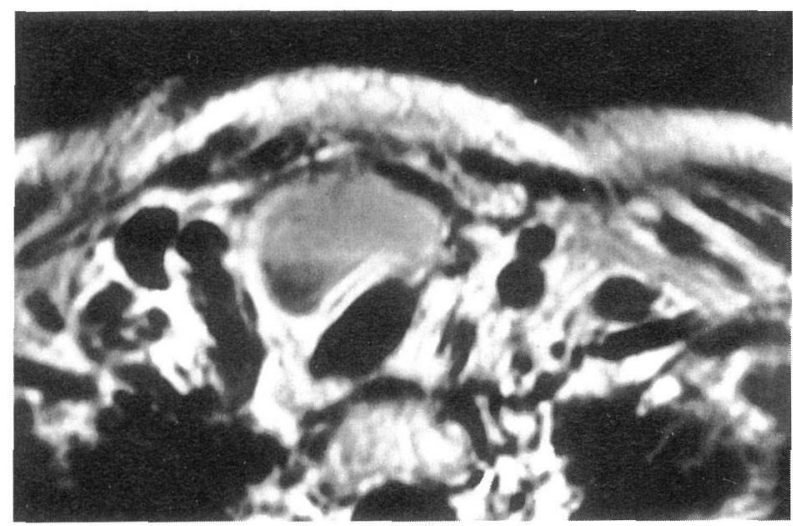

図 $4 \mathrm{Gd}$ 造影 $\mathrm{T} 1$ 強調 MRI 軸位断 界面形成を認める。
フィーでは甲状腺右葉下極に cold area 認め， ${ }^{201} \mathrm{~T} 1$ シ ンチグラフィーでは明らかな異常集積や wash out の遅 延は認めなかった。

3 月16日，全身麻酔下に囊胞核出術を施行した。䨞胞 の大きさは $46 \times 35 \times 30 \mathrm{~mm}$ で，褧胞壁は厚く，約 15 Cc の血性内容液を有していた(図 5 ).

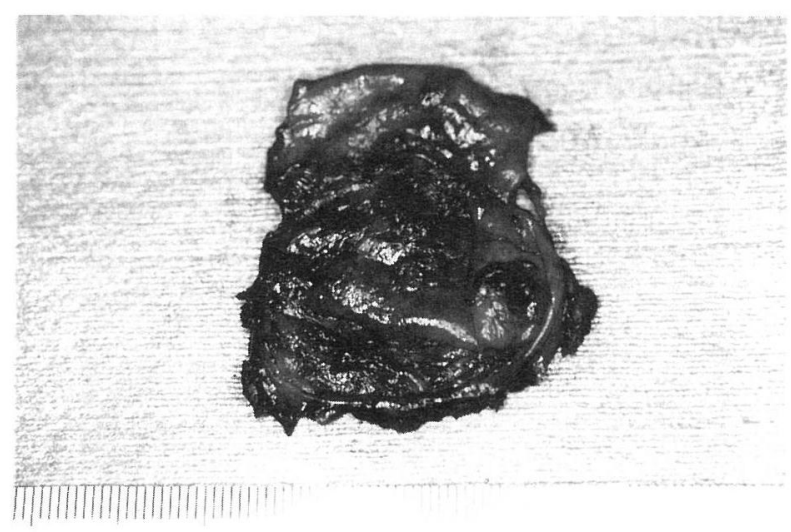

図 5 摘出標本

約 $15 \mathrm{cc}$ の血性内容液を有していた。

病理組織学的所見 : 摘出した囊胞壁の病理組織標本の 顕微鏡像である(図 6 )。囊胞壁には線維性結合織とそれ に隣接する大小不揃いの濾胞構造を認め, 一部には濾胞 の集合した結節性変化もみられた．上皮性細胞に悪性を 示す像を認めなかった。以上より，良性囊胞性変化をき たした結節性過形成巣岕るいは濾胞腺腫と考兄られた。

術後， CT にて気道狭窄は完全に消失していることを 確認した。をた甲状腺機能の低下もきたさなかった。

\section{考察}

甲状腺腫瘍性疾患が原因で気道狭窄をきたし，気道確 保のため気管内挿管や気管切開を要することは決して 稀ではない，腫瘍による上気道狭窄に対して気管切開を 要したもののうち，約 $10 \%$ が甲状腺腫瘍であるとされ る1)。また Calcaterra ら ${ }^{2)}$ は，甲状腺腫瘍性疾患269例の 万ち15例 (5.6\%) 飞気管の圧排，偏位認め， 3 例 ( 1 \%) 気管切開が必要であったとしている．その 3 例の らち 2 例は良性腫瘍， 1 例は乳頭癌と濾胞癌の合併であ った。

一般に著明な気管の狭窄を認める甲状腺腫瘍の場合， 


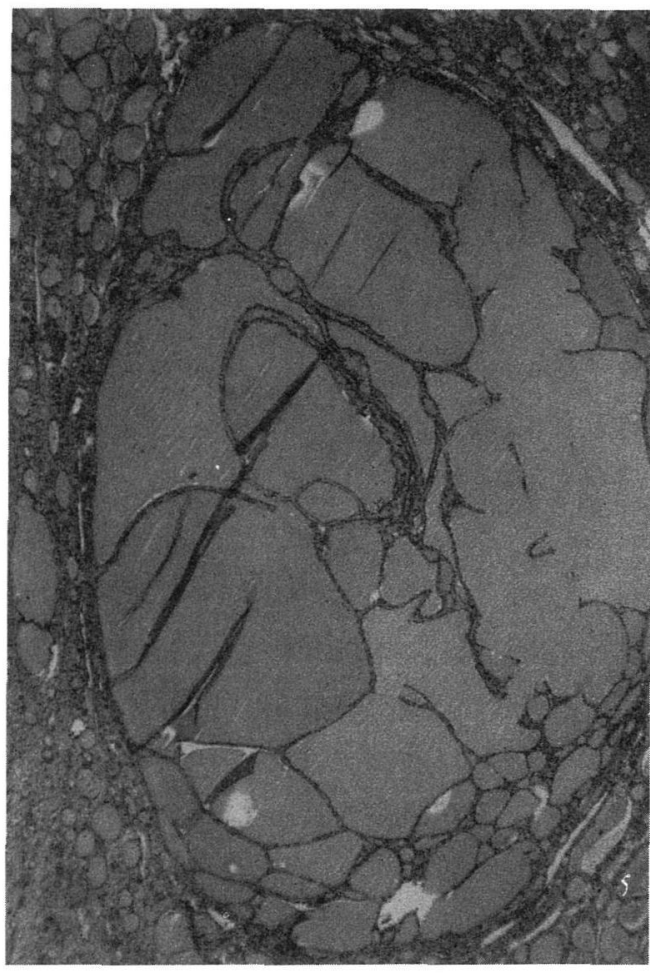

図 6 病理組織像 $(\mathrm{HE}$ 染色 $\times 20)$

線維性結合織とそれに隣接する大小不揃いの濾胞構造を 認める。

一部には濾胞の集合した結節性変化もみられる。

まず悪性腫瘍，特に未分化癌を考学ることが妥当であ る3)。亦た以前から存在した腫瘍が急激に大型化する場 合は，分化癌の未分化転化を第一に考光なくてはならな (4)．本症例は約 30 年前より前頸部腫瘤を自覚して特り， 受診の約 1 週間前より急速に増大し気管の著明な狭窄を 伴っていたことから，まず分化癌の未分化転化を疑った。

しかし稀ではあるが，良性腫瘍でも腫瘍内出血や囊胞 変性をきたした場合には，腫瘍の急速な増大・気道狭窄 を認めることがある5．

Close ${ }^{6)}$ は，急激な腫瘍の増大と気道狭窄を認めた 濾胞腺腫の 1 例について, 病理組織学的に腫瘍内出血々 虽胞変性を指摘している。

また宮崎らでは，急激な腫瘍の増大をきたした滤胞腫 瘍の 2 例に执いて, 病理組織学的にそれぞれ腫瘍内出血 と囊胞変性学認めたとしている。

本症例飞执いては, 呼吸困難を認め動脈血ガス分析上 も呼吸状態の悪化を認めたが，マスクによる酸素投与を
行いながら、レントゲン写真と CT による画像診断を優 先させた。画像上，気管狭窄が著明であったため，気道 の改善之腫瘍の病理組織学的検查を目的に気管切開術と 生検術を予定した。CT 上，腫瘍は囊胞性であることが 確認されていたので，穿刺吸引による囊胞の縮小と圧排 からの解放による気管狭窄の改善も考兄られた。しかし 囊胞内出血であった場合には穿刺による状態の悪化も予 想されたため，上記の術式とした。結果的には，囊胞壁 に切開を加え内容液を排液したことにより気管狭窄は著 明に改善され，気管切開は要さなかった。しかしながら， 気管の狭小化が可逆性であるとは限らず，気管切開は常 に念頭に执いて処置にあたるべきと思われる。

また気管内挿管によって気道確保を行い，必要な画像 検査を術前に施行することも 1 つの方法である. Close ら ${ }^{6)}$ は, 経鼻挿管にて気道を確保し， CT，99m Tc シンチ グラム，血管造影を術前に施行している。乙かし本症例 汸いては，CT上，気管内腔の前後の最小径は $3 \mathrm{~mm}$ であり，挿管チューブを抵抗なく挿入することは不可能 であると思われた。

呼吸困難をきたした機序は図 7 のごとく考えられる. 腫瘍が急速に増大した原因としては腫瘍内出血と襄胞変 性が挙げられるが，本症例は術中所見挹よび病理所見か ら推察すると, 腫痬内出血よりはむしろ囊胞変性が考光 られる。腫瘍の急速増大により圧迫を受けた気管の内腔 は狭小化し, また上気道感染により喀痰が増加し, 呼吸 困難に至ったと思われる．

甲状腺囊胞の治療法として，超音波診断上実質が見ら れない場合は自然に縮小することもありまた穿刺を繰 り返すことにより触知し得なくなることもあるので手術 の必要はないとする考光もある8). しかし，本症例のご

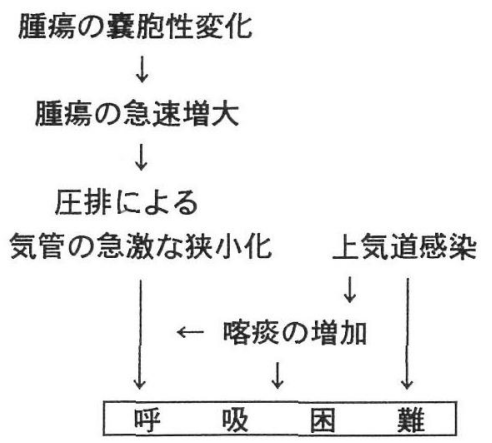

図 7 呼吸困難をさたした機序 
とく急速に増大してきたもの，圧迫症状を有するものな どは，良性腫瘍性病変でも手術を考慮する9)ことが適切 であると思われる. 今回我々は, 生検による組織学的診 断がついた後, 根治手術が必要と判断し, 霊胞核出術を 施行した。一般的には，甲状腺良性腫瘍性病変に対する 術式は部分切除, 片葉切除, あるいは亜全摘術を行うべ きとされる99. しかし，本症例に执いては正常甲状腺は 健側の左葉が非常に小さくまた囊胞は右葉から峡部にか けて存在していたため, 甲状腺機能温存のためには核出 術が適切であると考えた。

$$
\text { まとめ }
$$

1 ）急速に増大し呼吸困難をきたした甲状腺霬胞の 1 症例を報告した.

2) 呼吸困難をきたした機序として，囊胞が気管を圧 排したことによる気道狭窄と, 上気道炎による痰の増加, 喀痰による気道閉塞などが考兄られた。

3) 甲状腺霊胞においても気管狭窄をきたすことがあ り，早急な気道確保と適切な治療を行らことが重要であ る.

なお本論文の要旨は第 46 回日本気管食道科学会 (平成 6 年 10 月, 宇都宮)においてロ演した.

\section{参考文献}

1 ）冨田吉信, 山本智矢 : 腫瘍による気道狭窄の評価とその対 策. 日気食会報 $45 ： 142,1994$.

2 ) Calcaterra TC and Maceri DR : Aerodigestive dysfunction secondary to thyroid tumors. Laryngoscope $91: 701 \sim 707$, 1981.

3 ）海野徳二：呼吸困難について上気道とその診断. JOHNS 5 : 1179 1184, 1989.

4 ) 藤本吉秀 : 結節性甲状腺腫 - 甲状腺癌. 臨床と研究 62 : 2112 2116, 1985

5 ) Massie JD, Austin HM and Tarcan Y : Rapid thyroid enlargement; intracystic hemorrhage. Clin Nucl Med $6: 583,1981$.

6 ) Close LG, Costin BS and Kim EE : Acute symptoms of the aerodigestive tract caused by rapidly enlarging thyroid neoplasms. Otolaryngol Head Neck Surg 91 : 441 445, 1983.

7 ) 宮崎 巨, 細島弘行, 宮内博史, 他 : 急速に増大した甲状 腺腫瘍の 3 症例. 耳鼻臨床 $83: 1847 \sim 1853,1990$.

8 ）伊藤国彦：甲状腺良性腫瘍. 耳喉 $55: 819 \sim 825,1983$.

9）久 育男：甲状腺・上皮小体の腫瘍. JOHNS 9:1751 1756, 1993.

$$
\left(\begin{array}{l}
\text { 原稿受付: 平成 } 6 \text { 年 } 12 \text { 月 } 19 \text { 日 } \\
\text { 原稿採択 : 平成 } 7 \text { 年 } 1 \text { 月 } 11 \text { 日 } \\
\text { 別刷請求先 : 葍田俊樹 } \\
\text { 干 } 320 \text { 宇都宮市中央本町 } 4-17 \\
\text { 栃木県済生会宇都宮病院耳鼻咽喉科 }
\end{array}\right)
$$

